\title{
THE COPPING STRATEGIES IN REDUCING ANXIETY WHILE TEACHING EYL
}

\author{
Mustika Yuliani $^{1}$, Gabriella Maria Mancelina Sintu ${ }^{2}$, Rasi Yugafiati ${ }^{3}$ \\ ${ }^{1}$ IKIP Siliwangi Bandung \\ ${ }^{2}$ IKIP Siliwangi Bandung \\ ${ }^{3}$ IKIP Siliwangi Bandung \\ ${ }^{1} \underline{\text { mustikayuliani2014@gmail.com }},{ }^{2}$ gabriellamancelina@yahoo.co.id,${ }^{3}$ \\ tanya.rasiyugafiati@gmail.com
}

\begin{abstract}
Teaching English for Young Learner is not easy for several students. They face the obstacles in applying the science of pedagogy for Young Learners. The also have barriers to interact with children. However the teaching learning process may enjoyable if both of teachers and learners get fun together. This research examines what obstacles faced by several students when teaching English for Young Learners. This study also aims to explore the phenomenon of how reducing these anxiety. This research uses descriptive qualitative. There are seven persons as participants in this research. The result shows that they feel dizzy, anxious, and various other anxiety symptoms. They are anxious about lack of focus of young learners, mispronounce, inappropriate action, and unruly learners. The copping strategies are : prepare and understand the material correctly, find out students' characteristics, take a breath, and drink. They reduce the anxiety while teaching English for young learners with well prepare and the result are tranquility, believe, and pleasures.
\end{abstract}

Keywords: copping strategies, reducing anxiety, teaching EYL

\section{INTRODUCTION}

In this globalization era, English is international language that all of countries in the world can use it, and also English becomes a material for final examination in Indonesia and all of students have to pass it (Aryana and Apsari, 2018). Some people in Indonesia believe that English is very important as tool for communication. Thus, although English is not their mother tongue language, it is thought in schools. Even English nowadays is thought since young learner at kindergarten. It is known that teaching English at kindergarten is not as easy as seen. Young learners still focus on their worlds, especially they still observe their environment. They also have difficulties to concentrate in one subject in concentration for long period. Thus, the jobs for teachers to teach English in kindergarten are challenging.

On the other hand, there are some universities that concern on English teaching. The departments are mostly called English Education Department. The university students who learn there are asked to be skill-full in teaching English, especially in the kindergarten, elementary school, junior and senior high school. Poorly, some university students get anxious in teaching English for young learner. As Wilson (2002) says that a limited amount of stress can have a positive impact on motivation and creativity of teachers, meanwhile excessive 
pressure can have a negative impact on them. If the university students can handle their anxiety in teaching English to young learners, they can be well motivated. Unfortunately, if they can not find their copping strategies, they may get stress-full. In this research, the researcher would like to investigate their learning strategy in learning English speaking skill. Based on the background above, the researcher would like to do further research entitled The Analysis of Learning Strategy in Speaking Skill: The Copping Strategies In Reducing Anxiety While Teaching EYL.

\section{Anxiety}

Olatoye (2009) explains that the form of worry and restlessness can be appeared when people bear down their life. Both of worry and restlessness are parts of the university students' feeling when they are anxious in teaching English for young learners. It is related to the statement of Numrich (1996) who finds that language teachers experience anxiety as a part of problems. The problem is the anxiety will influence how the university students teach. Any form of anxiety in teaching such as behavior, beliefs, even feeling can affect the teaching. As Yoon (2012) states that anxiety actually is a normal feeling of human and expressed by any internal or external changes, because of uncertain situations, or even feeling of uncertainty.

\section{Anxiety Level}

Anxiety level may be various in the university students' experience. Even it can be shown in different reaction. "The degree of arousal in relation to one's adaption level will determine or not there will be a positive or negative effective experience" (Spielberger \& Sarason, 1985) cited in (Nemati, 2012). Anxiety can be categorized as permanent nature if it is viewed from global level, and categorized as particular act if it is seen from situational level (Brown, 2000) cited in (Ohata, 2005). It is the further research which has been held by Yugafiati (2015). As she finds that level is actually good for improving good academic performance. Furthermore, she reveals the phenomenon that the level of anxiety can be categorized into three groups : high level anxiety, moderate level anxiety, and low level of anxiety.

\section{Sources of Anxiety}

There are several potential sources of language anxiety such as the learner, the teacher, and the instructional practice (Young, 1991).

\section{Young Learners}

The decision about what and how to teach English depends on the learners period. People with different ages have different needs, competencies, and cognitive abilities. It makes the real understanding of why elementary school children learn a lot of English for example, through play, while adults can learn through abstract thinking. In addition, there are some other considerations such as length of the learning period and the young learners characteristics.

Young children learn differently from adolescents, and adults in the following areas. They respond to meaning even though they do not understand individual word; learn indirectly from their surroundings; explore from what they see and hear touch and interact; exhibit learning enthusiasm and curiosity about the world around them; have individual attention needs and approval from the teacher; talk about themselves, and responding when their lives being the main topic in the classroom; and have limited attention spans; unless the activity is really fun that does not quickly bore them, loses interest after about 10 minutes (Harmer, 2003). 
Slattery \& Willis (2001) deliver the teaching tips for very young learners (seven years old or younger) by introducing English slowly with fun activities; helping children feel safe by repeating familiar activities, such as singing and rhyme; repeating in English what children say in their mother's language; using puppets to speak in English; using pictures and photos; and conveying many stories using images as support. Shin \& Crandall (2006) in (Sadiq, 2017) explains that the teacher who teach EYL can encourage the students by visuals, realia, and movement. The university students who teach English to young learners should find the appropriate assessment. It is because the teacher's hard work in establishing a motivating atmosphere and positive attitudes towards learning English can be severely damaged to young learners when it comes to assessment (McKay, 2006) in (Yildirim \& Orsdemir, 2013).

Sukarno (2008) states that In teaching-learning process, the English teachers must know the kind of language learning resources for young learners, as follows: Learning resources are the main materials which usually do in their daily lives; should be appropriate for children's aptitude, will, world, and so forth; the teacher should be familiar with English songs and games in English and able to order those materials into becoming interesting ones. Songs, stories, poems, and games a can be categorized as resources.

\section{METHOD}

This research is mainly descriptive qualitative. Descriptive research draws the collected data without any goals to get the general conclusion (Sugiyono, 2017). This study is conducted in IKIP Siliwangi Bandung. There are seven participants in the research. This study employs some data collection techniques, using one questionnaire as instrument, classroom observation, interview, and document analysis as triangulation. The data analysis in this study is conducted over the course. All the data gained from the data collections are analyzed gradually. The data from questionnaires are transcribed and subsequently categorized, then interpreted to answer the research questions. The triangulation from interview, classroom observation, and document analysis are also interpreted descriptively.

\section{RESULTS AND DISCUSSION}

\section{RESULT}

The result of this research can be seen below.

Table 1. Result of the Interview

\begin{tabular}{|c|c|c|c|}
\hline \multicolumn{4}{|l|}{ No. } \\
\hline & $\begin{array}{l}\text { Participants' feelings before } \\
\text { TEYL (without copping } \\
\text { strategy) }\end{array}$ & Reasons & $\begin{array}{l}\text { Participants' feelings before } \\
\text { TEYL (with } \quad \text { copping } \\
\text { strategy) }\end{array}$ \\
\hline 1 & $\begin{array}{l}\text { P1 feels dizzy, the Ss must be } \\
\text { noisy, the Ss must be unruly, the } \\
\text { Ss must be make P1 upset }\end{array}$ & $\begin{array}{l}\text { I worry if I produce wrong } \\
\text { pronunciation and they } \\
\text { follow it until adult. }\end{array}$ & $\begin{array}{l}\text { I prepare the material before } \mathrm{i} \\
\text { teach. I learn it well }\end{array}$ \\
\hline
\end{tabular}


No.

Participants' feelings before Reasons

TEYL (without copping strategy)

Participants' feelings before TEYL (with copping strategy)

P2 worries that the Ss will not I think that teaching toddlers pay attention. The Ss must be will be exhausting. I should hard conditioned. The Ss must be be patient. getting bored quickly, the Ss only have limited time to get concentration.
I find out their characters. It leads me to enjoy the learning teaching process. It helps me to be unanxious.

3

P3feels lazy, P3 worry if the ss I worry if i misspelling or will be fussy produce pronunciation.
I see interesting things on my gadget to boost my mood. I inhale exhale my breath. I pray.

\section{4}

P4 get anxious because P4 never I think they are hard to be teaching the kindergarten class regulated.

I pray, take a deep breath, or They are finicky.

\section{5}

P5 feels nervous, P5 worries if he can not control the Ss
I just worry about my attitude. I will blame my self if they copy my bad attitude. It is because the kindergarten students just follow what they see.$$
\text { the see. }
$$

\section{I put trust on me.}

e
P6 feels anxious and worries. I worry if I give wrong I try to bare with the situation explanation related to and understand the Ss's grammar and vocabulary emotions. mastery

7

P7 worries
I worry if the students do not understand what I explain
Take a deep breath, well prepare and learning by doing

Based on table 1 above, there are seven participants who participate in this research. The table 1 explains about their and their coping strategies. The P1 feels dizzy. On his point of view, the young learners must be noisy, unruly, and make him upset. It is because he worries if he produces wrong pronunciation and they follow it until adult. His coping strategy is preparing the material before teaching. He learns the material well.

Based on table 1 above, P2 worries that the the young learners will not pay attention. She thinks that the young learners must be hard conditioned. The young learners must be getting bored quickly. The young learners only have limited time to get concentration. Her coping strategies are finding out their characters. It leads her to enjoy the learning teaching process. It helps her to be unanxious. 
Table 1 shows that P3 feels lazy. P3 worries if the young learners will be fussy. He worries if he misspelling or produce wrong pronunciation. He does some coping strategies. He sees interesting things on his gadget to boost his mood. He inhales exhales his breath. He also pray.

Table 1 reveals the phenomenon that $\mathrm{P} 4$ get anxious because $\mathrm{P} 4$ never teaching the kindergarten class. She thinks the young learners are hard to be regulated. She thinks that the young learners are finicky. Her coping strategies are praying, taking a deep breath, or drinking.

Table 1 explains that P5 feels nervous, P5 worries if he can not control the Ss. He just worries about his attitude. He thinks that he will blame his self if they copy his bad attitude. It is because the kindergarten students just follow what they see. Thus, his coping strategy is putting trust on himself.

Table 1 above shows that P6 feels anxious and worries. She worries if she gives wrong explanation related to grammar and vocabulary mastery. Her coping strategy is trying to bare with the situation and understanding the young learners emotions.

Table 1 explains that P7 worries. He worries if the young learners do not understand what he explains. Thus, his coping strategy is taking a deep breath, well preparing and learning by doing.

Those are the explanation of the result of this research.

\section{Discussion}

As (Wilson, 2002) says that a limited amount of stress can have a positive impact on motivation and creativity of teachers, meanwhile excessive pressure can have a negative impact on them. Luckily, the anxiety level of the participants can be categorized as a limited amount of stress. Thus, they can give good respond to deal with their duty in teaching English for young learners. The result also proves the theory that the form of worry and restlessness can be appeared when people bear down their life (Olatoye, 2009). The P1 feels dizzy when he is going to teach the young learners. It can be concluded that P1 feel restlessness .

The positive or negative effective experience will determine degree of arousal (Spielberger \& Sarason, 1985) cited in (Nemati, 2012). All of the participants get anxiety. Their anxiety because of their mindset in thinking of the teaching. If anxiety is seen from situational level, it can be categorized as particular act it (Brown, 2000) cited in (Ohata, 2005). Thus, the participants are in the situational level, moreover they can handle their anxiety. As (Numrich, 1996) explores that language teachers experience anxiety as a part of problems. The participants who will teach English to young learners are normally get worry and anxious. Since the level of anxiety can be categorized into three groups : high level anxiety, moderate level anxiety, and low level of anxiety (Yugafiati, 2015), it can be concluded that the participants get low and moderate anxiety. The P1 feels dizzy, P2 worries that the the young learners will not pay attention, P3 feels lazy, P4 get anxious because P4 never teaching the kindergarten class, P5 feels nervous, She worries if she gives wrong explanation related to grammar and vocabulary mastery, P6 feels anxious and worries. And P7 also get worries. However, those phenomenon do not matter as (Yoon, 2012) states that anxiety actually is a normal feeling. (Young, 1991) explains about potential sources of language anxiety.

From the table 1 above, the research reveals the phenomenon that the participants' anxiety come from the young learner. The P2 worries if young learners must be getting bored quickly. This 
anxiety related to the theory that young learner loses interest after about 10 minutes (Harmer, 2003: 38). Luckily, the participants do coping strategies by preparing materials well such as the teaching tips by (Slattery \& Willis, 2001). (Shin \& Crandall, 2006) in (Sadiq, 2017) explains that visuals, realia, and movement can encourage the students. The preparation material for teaching English for young learner can conclude those idea. (Sukarno, 2008) states that In teaching-learning process, the English teachers must know the kind of language learning resources for young learners. The more participants prepare language learning resources, the better they can reduce the anxiety.

\section{CONCLUSION}

There are seven persons as participants in this research. The result shows that they feel dizzy, anxious, and various other anxiety symptoms. They are anxious about lack of focus of young learners, mispronounce, inappropriate action, and unruly learners. The copping strategies are : prepare and understand the material correctly, find out students' characteristics, take a breath, and drink. They reduce the anxiety while teaching English for young learners with well prepare and the result are tranquility, believe, and pleasures. It is normal for the university students who will be teacher being nervous and anxious. Many reason for them to feel that feeling. The most important things in knowing their feeling, identifying their reasons, and finding out the appropriate strategies to reduces the anxiety level.

\section{ACKNOWLEDGMENTS}

Praise to Allah who has given us knowledge healthy and opportunity. The accomplishment of this research paper is made possibly because of Allah's help and mercy. Shalawat and salam are presented to our prophet Muhammad SAW, who has brought people from the darkness into brightness age of knowledge. Finally, this final project can be finished on time, the article is entitled "The Copping Strategies in Reducing Anxiety While Teaching EYL"

\section{REFERENCES}

Aryana, S., \& Apsari, Y. (2018). ANALYSING TEACHER'S DIFFICULTIES IN TEACHING LISTENING. ELTIN JOURNAL, Journal of English Language Teaching in Indonesia, 6(2), 100-106.

Brown, H. D. (2000). Teaching By Principles. Teaching by Principles: An Intéractive Approach to Language Pedagogy. Longman Publisher.

Harmer, J. (2003). The Practice of English Language-Teaching (third). England.

McKay, P. (2006). Assessing Young Language Learners. Cambridge: Cambridge University Press.

Nemati, A. (2012). On the Dimensions of Test Anxiety and Foreign Language Learners, 3(April), 97-102. https://doi.org/10.5897/IJEL11.116

Numrich, C. (1996). On Becoming a Language Teacher: Insight From Dory Studies. TESOL Quarterly, 30(1), 1-3. Retrieved from https://doi.org/10.2307/3587610

Ohata, K. (2005). Potential Sources of Anxiety for Japanese Learners of English : Preliminary Case Interviews with Five Japanese College Students in the U . S ., 9(3), 1-21.

Olatoye, R. A. (2009). Students ' Test Anxiety, Motivation for Examinations and Science Achievement in Junior Secondary Schools in Ogun State , Nigeria, 1(10), 194-198.

Sadiq, J. M. (2017). Anxiety in English Language Learning : A Case Study of English Language Learners in Saudi Arabia, 10(7), 1-7. https://doi.org/10.5539/elt.v10n7p1

Shin, J. K; Crandall, J. (2006). Teaching English To Young Learners Around the World: An 
Introduction. English Teaching Forum, 2.

Slattery, Mary; Willis, J. (2001). English for Primary Teachers. Oxford University Press.

Spielberger, C. D; Sarason, I. G. (1985). Stress and Anxiety. Washington: Hemispehere Publishing Corporation.

Sugiyono. (2017). Metode Penelitian Kuantitatif, Kualitatif, dan R\&D. Bandung: Alfabeta.

Sukarno, T. M.---. (2008). Teaching English to Young Learners and Factors to Consider in Designing the Materials. Jurnal Ekonomi Dan Pendidikan, 5(1), 57-73.

Wilson, M. (2002). Six Views of Embodied Cognition. Psychonomic Bulletin \& Review, 9(4), 625-636.

Yildirim, R., \& Orsdemir, E. (2013). Performance Tasks as Alternative Assessment for Young EFL Learners : Does Practice Match the Curriculum Proposal ?, 5(3), 562-574.

Yoon, T. (2012). Teaching English Though English : Exploring Anxiety in Non-native Preservice ESL Teachers, 2(6), 1099-1107. https://doi.org/10.4304/tpls.2.6.1099-1107

Young, D. J. (1991). Creating a Low-Anxiety Classroom Environment: What Does Language Anxiety Research Suggest? Blackwell Publishing, 75(4), 426-439.

Yugafiati, R. (2015). Students ' Test Anxiety: Its Sources And Their Coping Strategues ( A Study in One of Vocational Schools in Sukabumi ). UPI. 